This is a self-archived version of an original article. This version may differ from the original in pagination and typographic details.

Author(s): Saloviita, Timo

Title: Outcomes of teacher education in Finland : subject teachers compared with primary teachers

Year: 2019

Version: Accepted version (Final draft)

Copyright: @ 2019 Informa UK Limited, trading as Taylor \& Francis Group.

Rights: In Copyright

Rights url: http://rightsstatements.org/page/InC/1.0/?language=en

Please cite the original version:

Saloviita, T. (2019). Outcomes of teacher education in Finland : subject teachers compared with primary teachers. Journal of Education for Teaching, 45(3), 322-334.

https://doi.org/10.1080/09589236.2019.1599504 
Outcomes of Teacher Education in Finland: Subject Teachers Compared with Primary Teachers

Timo Saloviita

Department of Teacher Education, University of Jyväskylä, Jyväskylä, Finland

Timo Saloviita, Department of Teacher Education, University of Jyväskylä, P.O. Box 35, FIN-40014 Jyväskylän yliopisto, Finland. E-mail: timo.saloviita@jyu.fi,

GSM: +358 408053373

http://orcid.org/0000-0001-6723-3675

Final draft 


\section{Outcomes of Teacher Education in Finland: Subject Teachers Compared with Primary Teachers}

An exit survey performed for graduating students is an economic way to assess the outcomes of teacher education. In this study, exit survey data were collected from eight cohorts of Finnish student teachers who graduated between the years 2008 and 2015. A final sample consisted of 1102 preservice primary and subject teachers. A 10-item scale based on INTASC standards of teacher competency was used to measure graduates' satisfaction regarding the knowledge and experience they had attained. This paper concentrates especially on the results of subject teachers and comparisons between the two teacher categories. The profile of the participants was uneven across domains. The highest means were observed in the domain of planning, while the lowest were in the domain of special education. Factor analysis of the scale produced two factors: instructional efficacy and pedagogic efficacy. Subject teachers scored higher than primary teachers in instructional efficacy, while primary teachers exceeded subject teachers in pedagogic efficacy. Arts, crafts and physical education teachers scored higher than other subject teacher groups. The results indicated the importance of teaching practice in the formation of teacher competence. In the future special attention should be given to the domains that obtained the lowest scores.

Keywords: survey; teacher education outcomes; Finland 


\section{Introduction}

The efficacy of teacher education programmes is an issue of substantial political interest in many countries. In the United States (US), accreditation standards have been developed to support the planning and evaluation of these programmes. In 1992, the Interstate New Teacher Assessment and Support Consortium (INTASC) developed 10 core competencies for teachers (Council of Chief State School Officers 1992). An updated version of the standards was published in 2011 (Council of Chief State School Officers 2013). The INTASC standards have been used as the basis for writing survey items for evaluations of teacher education programmes (Darling-Hammond et al. 2012; Wilkerson 2012). The Council for the Accreditation of Educator Preparation (CAEP) expanded these standards to include other aspects of teacher preparation as well (CAEP 2016). In 1992, the Council for Exceptional Children (CEC) began to develop teaching standards for special education teachers. In their current form, the standards for initial preparation include the domains of learner development and individual learning differences, learning environments, curricular content knowledge, assessment, instructional planning and strategies, professional learning and ethical practice, and collaboration (CEC 2018). These domains are close to those in the INTASC standards.

In Finland, the government has shown steady interest in teacher education, which also has been regulated by law in more detail than any other academic curriculum (Act 794/2004; Finnish Government 2015). Despite the government's devotion to the field, interest in evaluating the outcomes of teacher education has not been as pronounced in Finland as in the US, where the evaluation of graduates' performance is a legal requirement (DarlingHammond 2006). 
Three main ways to assess the effectiveness of teacher education programmes include assessing the progress of student learning outcomes, making observations in the classrooms, and surveying opinions (American Psychological Association 2014). Giving exit surveys to graduating students is an economical way to evaluate teacher education outcomes. Such surveys make it easy to review students' opinions and satisfaction towards their studies. Many teacher preparation programmes have adopted this kind of evaluation. As a prerequisite for these surveys, a good analysis is required to determine the type of knowledge and skills needed for successful teaching practice. One solution is to use the standards mentioned above. However, they have been rarely used as outcome measures in teacher education research (Blanton, Sindelar, and Correa 2006; Kim, Andrews, and Carr 2004). One example of the use of CEC standards is the study by Nevin, Thousand, Parsons, and Lilly (2000). Another example is the Stanford Teacher Education Program (STEP). The survey contains 36 items, derived from the INTASC core standards, asking how well the programme has prepared participants to engage in each domain of teaching (Darling-Hammond, Eiler, and Marcus 2002). Other measures developed include, for instance, the National Survey of Teacher Education Program Graduates (Loadman et al. 1999; Thomas and Loadman 2001). The main problem with student surveys is that they are only an indirect measure of success, as the graduates' feelings of preparedness do not directly correspond with their real success as teachers. However, significant correlations have been found between the students' self-reports on their preparedness and their sense of self-efficacy, which in turn have been found to correlate with teachers' real success in the classroom (Darling-Hammond, Chung, and Frelow 2002). A review of the approaches to evaluate teacher effectiveness gave careful support for the use of teacher self-report measures while warning that they are susceptible to 
social desirability (Goe, Bell, and Little 2008). When various ratings have been compared, the best predictor of student achievement has been the students' ratings of their teachers, not the teachers' self-ratings or teacher ratings made by the principals (Wilkerson, Manatt, Rogers, and Maughan 2000). Wayne and Youngs (2003) reviewed studies on the relationship between student achievement gains and teachers' characteristics. They found that students learn more from teachers who had better teachers college ratings or test scores. In the case of certification, degrees or coursework, findings were less clear, except in mathematics, where teachers' content knowledge was found to be essential. Similar results were obtained in the review by Darling-Hammond (2000).

The evaluation results of teacher training programmes have differed from each other in exit surveys given to graduates. Huang and Oga-Baldwin (2014) used the 36-item scale of Darling-Hammond (2006) in a study of 408 Japanese and 525 Taiwanese students who graduated from teacher training programmes. They observed that the Taiwanese university students demonstrated a higher sense of preparation than the Japanese students.

Ingvarson, Beavis and Kleinhenz (2007) used a 46-item ACER Teacher Preparedness Inventory (TPI) to assess 1174 Australian teachers who just had finished their first year of teaching. The inventory was divided into several separate subscales. Significant variation was found between universities in the perceived preparedness of teachers. The teachers who felt best prepared for teaching had completed courses that gave them good content knowledge of the subject together with skills in planning, instruction and assessment. The use of INTASC standards to assess teacher candidate performance competencies in one university is described by Quattroche et al. (2004). 
The Finnish exit survey responses of 384 primary preservice teachers indicated that the satisfaction of graduates varied notably across content areas from $35 \%$ (special education) to $93 \%$ (planning). The scale used was based on 10 INTASC standards (Saloviita and Tolvanen 2017).

\section{Finnish Teacher Education}

Primary teacher education in Finland is based on master's degree university studies since 1979. The contents and structure of teacher training are defined in the legislation on teacher qualification (Government of Finland 1998). The length of studies is measured by European Credit Transfer System (ECTS) units, a standard applied on the academic attainments of university students across the European Union. One ECTS credit point is defined to equal approximately 27 hours of study. The master's degree for both primary and subject teachers contains 300 credit points in total.

The qualified subject teacher is entitled to work as a teacher in the basic school where they are mostly responsible for grades seven to nine (ages $13-15$ ). They may also work in grades one to three in the high school (ages $16-18$ ), or in other secondary school levels such as polytechnics. Besides subject studies (140 ECTS) completed in appropriate subject departments, the degree contains 60 credit points of "teachers" pedagogic studies" done in the department of teacher education. They include approximately 20 credit points of teaching practice.

Primary teachers in Finland work as classroom teachers for grades one to six in the basic school. The ages of their students vary from seven to 12 years. Typically, a five-year primary teacher programme consists of 'education' as a major subject comprising of about 140 ECTS. It contains study modules on educational psychology, child development, 
philosophy and sociology. Almost half of the contents are reserved for scientific methods and thesis writing. Approximately 25 credit points are reserved for teaching practice. The major includes at least 60 credit points of 'teachers' pedagogic studies', which are considered the core of educational knowledge needed by teachers. Additionally, the degree contains studies on the content knowledge of various school subjects (60 ECTS).

Besides the major, the degree for primary teachers demands a freely chosen minor, which is typically some school subject instructed by teachers (60 ECTS). Additionally, the studies must contain at least 60 credit points of multidisciplinary studies of various school subjects, such as mother tongue, mathematics, arts and crafts etc. These studies have a strong emphasis on the content pedagogy of each subject. The remaining 40 ECTS are made up of orienting studies, like languages or technology, and elective studies.

\section{Aims of the Study}

The aim of this study was to survey the perceptions of preparedness among graduating preservice subject teachers by assessing their satisfaction with the knowledge and experience gained during their studies in 10 domains of teacher competency, which were detailed in the INTASC standards (Council of Chief State School Officers 1992). The observed preparedness was compared across competency domains, major subject, year of graduation and gender. No previous research of this type was available for comparison, but the data contrasted with those obtained from primary teachers, some of which have been reported earlier (Saloviita and Tolvanen 2017). Because this prior study had postulated that teaching practice could have had a strong effect on the feelings of preparedness, the experienced importance of teaching practice was surveyed in this study. The psychometric 
properties of the 10-item scale measuring the preparedness were studied by performing a factor analysis and some other statistical analyses.

\section{Methods}

\section{Participants and setting}

The study was conducted in the University of Jyväskylä, which holds the oldest teacher education programme in Finland dating from the year 1863. The essence of the teacher education programme stresses the development of preservice teachers as autonomous reflective practitioners with high professional standards. The aim is to empower students with a strong academic identity. Teacher education is considered to represent a research-based orientation that would grow the students as future change agents and developers of their own work (Department of Teacher Education 2013).

The participants of this study were the preservice primary $(\mathrm{N}=384)$ or subject teachers ( $N=718)$ who graduated from the University of Jyväskylä during the years $2008-2015$ and who volunteered to participate in this study. For the sake of concision, they may be referred to later as simply teachers. Of them, $70 \%$ were women and $30 \%$ men. Their age varied between 22 and 53 years with a mean age of 27 years. The primary teachers were somewhat older $($ mean $=27.9$ years $)$ than the subject teachers $($ mean $=26.1$ years $)$.

The subject teachers were divided in four groups on the basis of their main subject. The groups were language teachers $(\mathrm{N}=309)$, science and mathematics teachers $(\mathrm{N}=199)$, humanities teachers (history, religion, philosophy, or psychology) $(\mathrm{N}=72)$, and teachers of arts, crafts and physical education $(\mathrm{N}=137)$. The grouping of subjects was based on their similarity while also guaranteeing the sufficient group size for statistical analyses. A large 
majority of language teachers were women $(83.6 \%)$, while in other subject teacher categories the genders were almost equally distributed. Other gender distributions are given in Table 1.

\section{Data Collection}

The data were collected using a paper-form questionnaire on which the students answered on the occasion of their last study requirement. For subject teachers, this was an academic one-day conference. For primary teachers, it was the individual maturity examination. In the cover letter of the survey, it was stressed that the participation was voluntary, anonymous and had no effect on the grading. The return rates are presented in Table 1.

\section{Questionnaire and INTASC Scale}

The questionnaire contained the usual basic demographic questions such as age and gender and some items concerning the university studies of the participant. The experienced importance of teaching practice was inquired only during the years 2014 and 2015 by asking participants to complete the following statement: 'Of all knowledge and skills, which I have achieved in teacher education, those obtained via teaching practice measure a percentage of...'. They had to select between the alternatives from $10 \%, 20 \%, 30 \%$ and so on until $100 \%$.

The INTASC Scale was constructed using 10 items measuring the perceived sufficiency of knowledge and experience achieved during teacher education. For this purpose, the original version of the INTASC standards were used (Council of Chief State School Officers 1992). Each of the 10 competence domains of the standards were transformed into a single item assessing the participant's satisfaction on the domain. In each item, the same introductory phrase was used: 'In my studies I have gained enough knowledge and experience of...' The text continued as follows: 
1. Content Pedagogy: disciplines in the school and the ways they are taught in the school.

2. Child Development: the learning and development of children.

3. Special Education: how to meet diversity in the classroom and how to differentiate instruction for diverse learners.

4. Multiple Instructional Strategies: a variety of instructional strategies to encourage students' development of critical-thinking, problem-solving and performance skills.

5. Motivation and Management: how to create individual and group motivation and how to generate learning environments that encourage positive social interaction and active engagement in learning.

6. Communication and Technology: effective communication techniques to foster active inquiry and collaboration.

7. Planning: planning the instruction.

8. Assessment: the use of assessment of learning outcomes.

9. Reflective Practice and Professional Development: become a reflective practitioner capable of continually evaluating one's own practices.

10. School and Community Cooperation: how to foster relationships with school colleagues, parents and the larger community outside the school.

The items were measured using a five-point Likert scale ranging from strongly disagree (1) to strongly agree (5). A short 10-item scale was selected for data collection instead of developing a larger and more detailed instrument. This was done in order to achieve as high a return rate as possible. The scale used in this study is based on the 1992 version. 


\section{Statistical Analysis}

The data were statistically analysed with IBM SPSS Statistics version 22. Besides statistical tests and Cohen's $d$, factor analyses were performed. The results were compared across competence domains, study years, teacher categories and some demographic variables. Standardised regression scores from factor analysis were used for further analyses. Polynomial contrast via a one-way ANOVA was used to test the linear trend across years in the INTASC scale sum scores.

\section{Results}

\section{Scale Properties}

The reliability of the scale as measured by Cronbach's alpha was $\alpha=0.66$ indicating an acceptable level. A factor analysis using the maximum likelihood method was performed for the 10 items on the scale. The Kaiser-Meyer-Olkin Measure of Sampling Adequacy was .752, indicating a moderate acceptability for factor analysis (Dziuban and Shirkey 1974). The Bartlett test of sphericity had a value of $p<.000$ indicating that the correlation matrix was an identity matrix. The applicability of the factor analysis for the data was thus confirmed. The communalities of the variables were not particularly high, remaining between .132 and .320 . On the basis of eigenvalues, Cattell's scree test and easiness of interpretation a two-factor solution was considered the most suitable. It was rotated into an oblique promax solution. The first factor explained $17 \%$ of the total variance and the second factor $4 \%$. Pattern matrix loadings were as follows. The first factor loaded high on content pedagogy (.633), instruction (.512), assessment (.358), cooperation (.342), special education (.329) and planning (.247). It was named 'instructional efficacy'. The second factor loaded 
high on child development (.466), communication (.433), reflective practice (.425) and motivation (.393). It was named 'pedagogic efficacy'.

\section{Satisfaction Scores: Preservice Subject Teachers}

The sum total results across all study years are presented in Table 2 as percentages, means and standard deviations. For easy access, the percentages were coded to only three levels (disagree, neutral and agree). When the means of all four study years were compared, differences were observed in five domains out of 10. They were Instruction, Motivation, Assessment, Content pedagogy, and Cooperation. Post-hoc tests (Tukey or Tamhane's T2) indicated that higher means were obtained every time in later years. Cohen's $d$ was calculated to measure the effect sizes of the differences by comparing the lowest mean to the highest mean in those cases in which the $F$-value was statistically significant. The effect sizes remained small or modest, with the exception of Content pedagogy in which a large effect size of $d=3.21$ was observed. When polynomial contrast via one-way ANOVA was used, a statistically significant positive linear trend across the years was found for total scores (contrast estimate $=1.754$, standard error $=.364, p=.000$ ). During the study years 2009 , 2011, 2014 and 2015, the sum total scores systematically increased from year to year, i.e. $34.7,35.1,36.3$ and 36.9 , respectively.

When subject teachers were compared across all study years by their main subject, a statistically significant difference emerged. The arts, crafts and physical education teachers scored higher than the other three groups in the INTASC sum scores (Table 3). They also scored higher for both factor variables. The effect sizes in pairwise comparisons for the sum scores varied from .54 to .85 . 
Male subject teachers had higher total means in the sum scale than female, $t(712)=$ $3.42, p=.001$, but the effect size was small, $d=.27$. When genders were compared across 10 domains, and separately in four teacher categories, the only observed difference at the $1 \%$ level was found in the category of science and mathematics teachers. Among them men had higher means than women in the domain of cooperation, $t(196)=2.67, p=.008, d=.36$. The age of the participants was not associated with any variable in the scale.

\section{Comparison between Preservice Primary and Subject Teachers}

Table 4 presents a comparison between the mean scores of primary and subject teachers across all study years. Several statistically significant differences were observed and $d$ values were calculated to indicate the effect sizes. In the sum total scores, the subject teachers scored somewhat higher than the primary teachers. When the two teacher categories were compared on the basis of standardised factor scores, the subject teachers scored higher than primary teachers on the factor of instructional efficacy, while primary teachers scored higher than subject teachers on the factor of pedagogic efficacy (Table 5). The results by domain and year of primary teachers are presented in a separate article (Saloviita and Tolvanen 2017).

\section{The Importance of Teaching Practice}

Teachers were asked what share of all the knowledge and skills they had achieved in teacher education they had obtained from teaching practice. The answer was given in a percentage. A total of 324 subject teachers and 69 primary teachers responded. The mean result among subject teachers was 70.4\% $(\mathrm{SD}=15.8)$ and among primary teachers $59.3 \%$ $(\mathrm{SD}=19.5)$. The difference between teacher categories as measured by Cohen's $d$ was .63.

\section{Discussion}


The exit survey performed for graduating preservice subject teachers revealed differences in student satisfaction across the domains and the study years. First, the participants' profiles in the 10 domains of the INTASC scale were uneven, with the extremes being lesson planning, which scored highest, and special education, which scored lowest. The differences indicate that the teacher education programme's attention to the various teaching competencies was uneven. The domains of cooperation, child development and special education will obviously need more attention in the future. In all these domains, less than half of the students were satisfied with the levels of skills and knowledge they obtained. The low scores of special education may reflect the relative indifference of the teacher education programme towards this area, which has its own separate teacher training programme. However, the existence of a separate profession does not make knowledge on special education less important to other teachers. On the contrary, the ongoing policy change has begun to underline the need for inclusive education in which mainstream teachers participate in the instruction of students with special educational needs. In addition, the Convention on the Rights of People with Disabilities (United Nations 2006) confirmed the obligation to develop inclusive education, which was also ratified by Finland in 2016.

The differences between the domains were almost identical among subject and primary teachers (see Table 4). The order of the domains seems to indicate the strong influence of teaching practice on attained skills and knowledge. Skills for which students received ample training during the teaching practice, such as lesson planning, rank high, while those in which they received less training, such as special education or cooperation, rank low.

The subject teachers were categorised in four groups on the basis of their major. The arts, crafts and physical education teachers were most satisfied with their studies. The 
unifying feature for them was the concrete nature of their major, which possibly affected the content of their studies and made them more practice-oriented.

The sum scores of the INTASC scale showed systematic progress across the study years. The graduating preservice subject teachers felt that they were better prepared than before, especially in content pedagogy, but also in other fields such as instruction or cooperation. The change in content pedagogy can possibly be explained by the curricular changes between the years under study. The proportion of content pedagogy was substantially increased after 2009 , and the studies were made more specific than before for each major. Even if the scores cannot rise infinitely, the change probably illustrates success in the development of the curriculum.

The sum total satisfaction scores for preservice primary and subject teachers were nearly the same, even if the difference was slightly in favour of subject teachers. For some of the items, the differences were higher. The subject teachers prevailed over primary teachers especially in the domain of content pedagogy. The primary teachers surpassed subject teachers especially in the domain of child development. This outcome indicates structural differences, which were further confirmed by the factor analysis. In it, the INTASC scale was divided into two factors, 'instructional efficacy' and 'pedagogic efficacy'. Subject teachers surpassed primary teachers in instructional efficacy, characterised by technical teaching skills. In contrast, primary teachers scored higher than subject teachers in the factor of pedagogic efficacy, which contained more psychological aspects of teaching, such as communication, motivation or child psychology. This finding may reflect differences between subject and primary teachers in the teaching profession as recently discussed, for instance, by Doumet (2018). Subject teachers may be more concerned about subject matter 
and primary teachers about individual children. It also brings to mind the division made by John Dewey between the child and the curriculum, which was 'below all other divisions in pedagogic opinion' (Dewey 1902, 4). For Dewey, 'pedagogy' was a more advanced approach in which the needs of the child were better taken into account than in curriculum-oriented thinking (Hyun, 2006).

Primary teachers complete four times more educational studies than subject teachers. Despite this, both were equally confident in their level of preparation for the teaching profession. This sounds like a paradox. One explanation for this may be provided by the theory of social comparison. Both teacher categories compare themselves with other people and find themselves to be better prepared for their profession than any other group. After all, they have received a formal qualification. Another explanation is methodological.

Satisfaction studies often find that the participants are satisfied with the programme reviewed, regardless of what it is. For example, a meta-analysis of 200 studies on satisfaction towards medical care indicated that approximately $80 \%$ of the participants confirmed their satisfaction in most of the studies (Hall and Dornan 1988). The absolute level of satisfaction may be, therefore, of little value as such. Instead, comparisons of satisfaction across some background variables may be more useful.

Another possible reason for almost equal levels of reported preparedness for teaching may be the nearly equal amounts of teaching practice in both curriculums. The participants were asked to evaluate the relative importance of the teaching practice in the formation of their knowledge and experience for teaching. The results showed that the estimated value of teaching practice was almost 10 times higher on average than its relative share in the overall degree. It clearly was the most appreciated component in the teacher education programme. 
The important role of teaching practice in creating the sense of self-efficacy has been demonstrated in prior studies, as well (Allsopp et al. 2006; Martins, Costa, and Onofre 2015).

The expressed importance of teaching practice seems to leave little space for other components of the curriculum in the minds of student teachers. These components, however, are highly valued by the official curriculum as a source of teacher competence (Department of Teacher Education 2013). They include knowledge in educational theory and research methods as prerequisites for a research-based teaching practice. From the perspective of teacher educators, it may seem that graduating students are too worried about their survival skills in the school while they do not sufficiently appreciate those more general skills they have attained in university.

Because the university programme under study underscored its theoretical and scientific orientation, it could be claimed that the INTASC scale did not correspond well with its goals. This criticism is at least partly justified. The items of the INTASC scale concentrate on pedagogical skills. Instead, in the university programme studied here, pedagogic knowledge was considered only one aspect of the teacher education curriculum. Other areas listed in the curriculum were ethical, aesthetic, intellectual, cultural and communicative expertise (Department of Teacher Education 2013). The goal setting was larger than just pedagogical know-how.

The limitations of this study include the difficulty to fully conceptualise the dimension measured by the INTASC scale. It was close to the idea of teacher self-efficacy, defined as a teacher's confidence in his/her capability to influence students' learning (Klassen et al. 2011). A popular instrument to measure teachers' self-efficacy is the Teachers' Sense of Efficacy Scale (TSES) developed by Tschannen-Moran and Woolfolk Hoy (2001). The items of the 
TSES define self-efficacy as the teacher's confidence to manage different educational challenges in the classroom, for instance, to what extent the teacher can use a variety of assessment strategies. The INTASC Scale, similarly, asked whether the student had gained enough knowledge and experience to assess educational outcomes. While the items look similar with each other, the focus of the INTASC items is narrower. It may be justified to say that the INTASC items measure a certain dimension (knowledge and experience) which credibly has an influence on the teachers' self-efficacy.

The INTASC scale used in this study was short and only narrowly surpassed the demand of sufficient reliability. The construct validity of the scale and its factorial structure were clarified by the empirical findings obtained. The samples of preservice primary and subject teachers compared in this study were of different size (384 and 718), and the confidence intervals in the analyses consequently different for both groups.

The present study revealed some areas of teacher education worthy of elaboration. One is the uneven profiles of teacher competencies among the graduating students. Especially, the need to develop better skills in special education requires more attention in the future. Another important finding was the importance given by preservice teachers to the role of teaching practice in relation to other parts of their curriculum. It is worth pondering whether its role could be enhanced by linking it more tightly with other content in teacher studies. The idea of research-based teacher education may also need some rethinking, at least regarding its seemingly low estimation in the minds of graduating students. Are its promises of theoretical depth and scientific orientation really achieved if the teaching practice is the issue that matters most? 


\section{Biographical Note}

Timo Saloviita is a Professor of Education at the University of Jyvaskyla, Finland. His research interests include teacher education and inclusive education.

\section{References}

Act 794/2004 (2004). Valtioneuvoston asetus yliopistojen tutkinnoista [Government decree on university degrees]. Finlex. http://www.finlex.fi/fi/laki/alkup/2004/20040794

Allsopp, D. H., D. De Marie, P. Alvarez-Mchatton, and E. Doone. 2006. "Bridging the Gap between Theory and Practice: Connecting Courses with Field Experiences." Teacher Education Quarterly 33 (1): 19-35.

American Psychological Association. 2014. Assessing and evaluating teacher preparation programs. APA task force report. http://www.apa.org/ed/schools/teachinglearning/teacher-preparation-programs.pdf

Blanton, L.P., Sindelar, P.T., and Correa, V. I. 2006. "Models and measures of beginning teacher quality". The Journal of Special Education 40 (2): 115-127.

Council for Exceptional Children. 2018. Special Educaior Professional Preparation. https://www.cec.sped.org/Standards/Special-Educator-Professional-Preparation$\underline{\text { Standards }}$

Council for the Accreditation of Educator Preparation .2016. The CAEP Standards. http://www.ncate.org/standards/introduction

Council of Chief State School Officers. 1992. INTASC model standards for beginning teacher licensing, assessment, and development: A resource for state dialogue. Washington, DC: Author. http://programs.ccsso.org/content/pdfs/corestrd.pdf 
Council of Chief State School Officers. 2013. INTASC model core for teaching standards: A resource for state dialogue. Washington, DC: Author.

Department of Teacher Education. 2013. Opettajankoulutuslaitoksen opetussuunnitelmat 2014-2017 [Curriculums of the Department of Teacher Education 2014-2017]. https://www.jyu.fi/edupsy/fi/laitokset/okl/opiskelu/luokanopettajakoulutus/luokanopet tajakoulutuksen-ops-2014-17

Darling-Hammond, L. 2000. "Teacher quality and student achievement: a review of state policy evidence." Education Policy Archives 8 (1): 1-44.

Darling-Hammond, L. 2006. “Assessing Teacher Education. The Usefulness of Multiple Measures for Assessing Program Outcomes.” Journal of Teacher Education 57 (2): $120-138$.

Darling-Hammond, L., Amrein-Beardsley, A., Haertel, E., and Rothstein, J. 2012.

“Evaluating Teacher Evaluation. "Phi Delta Kappan, March, Supplement 8-15.

Darling-Hammond, L., Chung, R., and Frelow, F. 2002. "Variation in Teacher Preparation. How Well Do Different Pathways Prepare Teachers to Teach?” Journal of Teacher Education 53 (4): 286-302.

Darling-Hammond, L., Eiler, M., and Marcus, A.2002. "Perceptions of Preparation: Using Survey Data to Assess Teacher Education Outcomes." Issues in Teacher Education 11 (1): $65-84$.

Dewey, J. 1902. The child and the curriculum. Chicago: The University of Chicago Press. Doumet, M-H. 2018. "How do primary and lower secondary teachers compare?" Education Indicators in Focus, January 2018 \#58.Paris: OECD Publishing. 
Dziuban, D., and Shirkey, E. C. 1974. "When is a Correlation Matrix Appropriate for Factor Analysis? Some Decision Rules.” Psychological Bulletin 81 (6): 358-361.

Finnish Government. 2015. Programme of Prime Minister Sipilä's Government. $\underline{\text { http://Valtioneuvosto.Fi/Sipilan-Hallitus/Hallitusohjelma }}$

Goe, L., Bell, C., and Little, O. 2008. Approaches to evaluating teacher effectiveness: a research synthesis. Washington, DC: National Comprehensive Center for Teacher Quality.

Government of Finland. 1998. Act on Teacher Qualifications (14.12.1998/986). Finlex.

Hall, J.A., and Dornan, M.C. 1988. "Meta-Analysis of Satisfaction with Medical Care: Description of Research Domain and Analysis of Overall Satisfaction Levels. " Social Science \& Medicine 27(6): 637-644.

Huang, C. J.-L-, and Oga-Baldwin, W.L. Q. 2014. “Assessing Outcomes of Teacher Education: Quantitative Case Studies from Individual Taiwanese and Japanese Teacher Training Institutions.” Asia-Pacific Educational Researcher. Published Online 13 August 2014. DOI 10.1007/S40299-014-0203-4.

Hyun, E. 2006. “Transforming instruction into pedagogy through curriculum negotiation. “Journal of Curriculum and Pedagogy, 3(1): 136-164.

Ingvarson, L., Beavis, A, and Kleinhenz, E. 2007. "Factor Affecting the Impact of Teacher Education Programmes on Teacher Preparedness: Implications for Accreditation Policy.” European Journal of Teacher Education 30 (4): 351-381.

Kim, M. M., Andrews, R. L., and Carr, D. L. 2004. “Traditional versus Integrated Preservice Teacher Education Curriculum. A Case Study. “Journal of Teacher Education 55 (4): $341-356$. 
Klassen, R. M., Tze, V. M .C., Betts, S. M., and Gordon, K. A. 2011. “Teacher Efficacy Research 1998-2009: Signs of Progress or Unfulfilled Promise?” Educational Psychology Review 23 (1): 21-43.

Loadman, W.E., Rahman, M.A., Freeman, D.J., McCague, G.J., and Brookhart, S.M. 1999. "Development of a national survey of teacher education program graduates." The Journal of Educational Research 93 (2): 76-89.

Martins, M., Costa, J., and Onofre, M. 2015. "Practicum Experiences as Sources of PreService Teachers' Self-Efficacy.” European Journal of Teacher Education 38 (2): $263-279$.

Nevin, A., Thousand, J., Parsons, A.S., and Lilly, M.S. 2000. “The kids keep me fresh!” Results of a follw-up survey of graduates from two special education programs who are teaching. Teacher Education Quarterly 27 (1): 87-108.

Quattroche, D.J., Watkins, S.D., Bolinger, K. Duarte, V. and Wepner, S.B. 2004. 'Improving the performance of teacher candidates: developing assessment through standards." Action in Teacher Education 26 (1): 43-52.

Saloviita, T., and Tolvanen, A. 2017. "Outcomes of Primary Teacher Education Finland: an Exit Survey.” Teaching Education 28 (2): 211-225.

Thomas, A.M., and Loadman, W.E. 2001. "Evaluating teacher education programs using a national survey." The Journal of Educational Research 94 (4): 195-206.

United Nations. 2006. Convention on the Rights of People with Disabilities. New York: United Nations. 
Wilkerson, J. R. 2012. "Measurement and Evaluation Perspectives on Scaling Teacher Affect with Multiple Measures.” The International Journal of Educational and Psychological Assessment 9 (2): 165-187.

Wayne, A. J., and Youngs, P. 2003. "Teacher characteristics and student achievement gains: a review." Review of Educational Research 73 (1): 89-122.

Wilkerson, D. J., Manatt, R. P., Rogers, M. A., and Maughan, R. 2000. "Validation of student, principal, and self-ratings in $360^{\circ}$ feedback for teacher evaluation." Journal of Personnel Evaluation in Education 14 (2): 179-192.

doi:10.1023/A:1008158904681 
Table 1. Study participants.

\begin{tabular}{|c|c|c|c|c|c|c|c|}
\hline \multirow[t]{2}{*}{ Year } & \multicolumn{3}{|c|}{ Preservice classroom teachers } & \multicolumn{3}{|c|}{ Preservice subject teachers } & \multirow[t]{2}{*}{ Total } \\
\hline & $\mathrm{N}$ & $\begin{array}{c}\text { Return rate } \\
\%\end{array}$ & $\begin{array}{c}\text { Female } \\
\%\end{array}$ & $\mathrm{~N}$ & $\begin{array}{c}\text { Return rate } \\
\%\end{array}$ & $\begin{array}{c}\text { Female } \\
\%\end{array}$ & \\
\hline 2008 & 68 & 57 & 78 & - & - & - & 68 \\
\hline 2009 & 40 & 56 & 78 & 177 & 71 & 72 & 217 \\
\hline 2010 & 61 & 88 & 71 & - & - & - & 61 \\
\hline 2011 & 56 & 75 & 82 & 216 & 89 & 66 & 272 \\
\hline 2012 & 54 & 61 & 83 & - & - & - & 54 \\
\hline 2013 & 52 & 58 & 79 & - & - & - & 52 \\
\hline 2014 & 53 & 58 & 76 & 170 & 70 & 64 & 223 \\
\hline 2015 & - & - & - & 155 & 69 & 60 & 155 \\
\hline Total & 384 & 65 & 78 & 718 & 77 & 66 & 1102 \\
\hline
\end{tabular}


Table 2. INTASC items in order of the mean $(\mathrm{N}=718)$

\begin{tabular}{lcccc}
\hline In my studies I have gained enough knowledge and & Disagree & Neutral & Agree & Total \\
experience of... & $\%$ & $\%$ & $\%$ & $\%$ \\
\hline
\end{tabular}

7. Planning

...planning the instruction

$\begin{array}{llll}5.3 & 2.9 & 91.8 \quad 100\end{array}$

9. Reflective Practice and Professional Development

becoming a reflective practitioner capable of

$\begin{array}{llll}8.4 & 17.5 & 74.1 & 100\end{array}$

continually evaluating one's own practices

4. Multiple Instructional Strategies

... a variety of instructional strategies to encourage

$\begin{array}{llll}13.2 & 8.6 & 78.1 & 100\end{array}$

student development of critical thinking, problem

solving, and performance skills

1. Content Pedagogy

...the disciplines in the school and the ways they are taught in the school

$\begin{array}{llll}14.3 & 8.5 & 77.2 & 100\end{array}$

5. Motivation and Management

...how to create individual and group motivation and how to generate learning environments that

$\begin{array}{llll}16.4 & 16.3 & 67.3 & 100\end{array}$ encourage positive social interaction and active engagement in learning

6 Communication and Technology

...effective communication techniques to foster active inquiry and collaboration

$\begin{array}{llll}19.1 & 22.0 & 58.9 & 100\end{array}$

8. Assessment

...the use of assessment of learning outcomes

$\begin{array}{llll}23.1 & 18.8 & 58.1 & 100\end{array}$

10. School and Community Cooperation

...how to foster relationships with school colleagues, parents and the larger community

$\begin{array}{llll}34.7 & 18.8 & 46.5 & 100\end{array}$
outside the school

2. Child Development

...the learning and development of children

$\begin{array}{llll}31.8 & 21.6 & 46.7 & 100\end{array}$

3. Special Education

...how to meet diversity in the classroom and how

$\begin{array}{llll}38.4 & 18.0 & 43.6 & 100\end{array}$ to differentiate instruction for diverse learners 
Table 3. Comparison between the scores of preservice subject teachers across major subject.

\begin{tabular}{lrlllll}
\hline Teacher Category & N & Mean & SD & $F$ & df & $p$ \\
\hline Sum total & 717 & & & 21.85 & 3,713 & .000 \\
Languages & 309 & 34.54 & 4.71 & & & \\
Science \& math & 199 & 35.47 & 4.70 & & & \\
Humanities & 72 & 36.03 & 4.43 & & & \\
Arts, crafts and & 137 & 38.33 & 4.24 & & & \\
physical education & & & & & & \\
\hline
\end{tabular}


Table 4. Comparison between the scores of preservice primary teachers and subject teachers.

\begin{tabular}{|c|c|c|c|c|c|c|c|}
\hline \multirow{2}{*}{ Teacher category } & \multirow{2}{*}{\multicolumn{2}{|c|}{$\begin{array}{l}\text { Primary } \\
\mathrm{N}=384\end{array}$}} & \multirow{2}{*}{\multicolumn{2}{|c|}{$\begin{array}{l}\text { Subject } \\
\mathrm{N}=718\end{array}$}} & \multirow{3}{*}{$t$} & \multirow{3}{*}{$p$} & \multirow{3}{*}{$d$} \\
\hline & & & & & & & \\
\hline Domain & M & SD & M & SD & & & \\
\hline 1. Content Pedagogy & 3.20 & 1.02 & 3.77 & .91 & -9.141 & $>.000$ & -.59 \\
\hline 2. Child Development & 3.69 & .81 & 3.15 & .98 & 9.832 & $>.000$ & .60 \\
\hline 3. Special Education & 2.80 & 1.07 & 3.07 & 1.04 & -4.077 & $>.000$ & -.26 \\
\hline 4. Instruction & 3.49 & 1.00 & 3.85 & .91 & -5.930 & $>.000$ & -.38 \\
\hline 5. Motivation & 3.55 & .94 & 3.60 & .88 & -.875 & .382 & \\
\hline 6. Communication & 3.50 & .90 & 3.45 & .88 & .825 & .410 & \\
\hline 7. Planning & 4.36 & .73 & 4.34 & .79 & .406 & .685 & \\
\hline 8. Assessment & 3.20 & 1.03 & 3.42 & .99 & -3.51 & .001 & -.22 \\
\hline 9. Reflective Practice & 4.20 & .74 & 3.87 & .85 & 6.534 & $>.000$ & .41 \\
\hline 10. Cooperation & 3.02 & 1.13 & 3.16 & 1.07 & -1.893 & .059 & \\
\hline Sum Total & 35.01 & 4.46 & 35.67 & 4.78 & -2.223 & .026 & -.143 \\
\hline
\end{tabular}


Table 5. Comparison between the scores of preservice primary teachers $(n=384)$ and subject teachers $(\mathrm{n}=718)$.

\begin{tabular}{ccccccc}
\hline & Mean & SD & $t$ & df & $p$ & $d$ \\
\hline Instructional Efficacy (Factor 1) & & & & & & \\
Primary teacher & -.211 & .776 & -6.51 & 1100 & $>.000$ & -.413 \\
$\quad$ Subject teacher & .113 & .792 & & & & \\
Pedagogical Efficacy (Factor 2) & & & & & & \\
$\quad$ Primary teacher & .101 & .728 & 3.211 & 1100 & $>.000$ & \\
$\quad$ Subject teacher & -.054 & .780 & & & & \\
\hline
\end{tabular}

